\title{
AN ANALYTICAL STUDY ON TEST STANDARDS FOR ASSESSMENT OF JUTE GEOTEXTILES FOR GLOBAL ACCEPTANCE
}

\author{
S.K. Ghosh ${ }^{1}$, R. Bhattacharyya ${ }^{2}$ \\ ${ }^{1}$ Associate Professor, ${ }^{2}$ Senior Research Fellow, Department of Jute and Fibre Technology, University of Calcutta, West \\ Bengal, India, ijtsk40@gmail.com,rajib8181@yahoo.com
}

\begin{abstract}
Geosynthetics made of man-made fibres, and used for addressing a host of geotechnical problems, have for the last two decades, registered a remarkable growth clinching about 95\% share of the total global demand in several fields such as erosion control, management of slopes, strengthening of roads, stabilization of embankments, protection of river banks, consolidation of soft soils etc. One such major application of Geosynthetic material is in the field of road construction which has become an established phenomenon worldwide. Recently, however, increasing environmental concerns concomitant with the alarming danger of carbon footprint generation have generated interest in and led to acceptance of natural Jute Geotextile (JGT) where this material plays a significant role for the purpose of reinforcement providing dimensional stability as well as cushioning effect to the road surface thereby improving the life cycle as well as maintenance cost of the road. With the increasing use of Jute Geotextile worldwide in combating geotechnical problems without hampering environmental sustainability, and the confidence with which they are being used is also developing amongst engineers, manufacturers and end users is opening new avenues for potential Jute Geotextile. Hence, there is a dire need for quality control in terms of testing and evaluation of Jute Geotextile demanding formulation of new standards for testing. The existing test standards for synthetic Geotextiles for evaluating different end use property parameters are not uniform globally i.e., these test standards vary from country to country. However, in the field of standardization for testing of different properties of Jute Geotextiles there is a paucity of data for formulation of specifications and quality control guidelines. Test standards for synthetic Geotextiles understandably do not exactly apply to JGT. While study is on to develop exclusive test and design standard for JGT, there is need to adopt any of the existing standards for synthetic Geotextiles that cater to the majority of requirements in the interim period. The paper suggests adoption of ASTM standards for testing JGT because of the wide range of test standards available and their credibility.
\end{abstract}

Keywords: Jute Geotextile, ASTM standards, Carbon foot print, Geotechnical Engineering, European Standards, CEN $* * *$

\section{INTRODUCTION}

The potential of Jute Geotextile (JGT) is complemented by the demand for these products in environmental protection and management. The Expert Committee on Textile Policy, constituted by Ministry of Textiles, Government of India, has in its report on August 1999 the potential of technical textiles in the country and has made strong recommendation for promoting its growth to enable India, Bangladesh, Nepal and all the other neighbouring jute growing countries to create a place as an entity in the International Technical Textile scenario. But for any application and supervision quality control tests are an essential part. Again, proper testing of technical textiles meant for geotechnical uses is critical to ensure their effective performance. The standards evolved for this purpose relate to synthetic Geotextiles only and are not uniform [1, 2]. The design is based on rigorous empirical exercise carried out individually in each country. The site conditions are apt to vary and so also the approach to design. While some sort of uniformity in testing methods could be achieved in case of synthetic Geotextiles after 'synthesizing' the standards available, no such standards have drawn up so far for Geotextiles made of different natural fibres such as Jute Geotextiles (JGT) [3]. In absence of testing standards for JGT, standards for synthetic Geotextiles are presently adopted for Geotextiles made of natural fibres. In view of the growing demand of JGT in particular, it is felt necessary to evolve exclusive application-wise standards for JGT.

The selection of JGT for a particular application in geotechnical engineering areas necessarily depends on adequate and suitable fabric properties and specific functional characteristics in respect of end-use requirements.

If these properties are technically inadequate for a particular application considering the limited durability of JGT and other natural Geotextiles, distress/failure could be a distinct possibility. On the other hand, if these properties meet the desired specifications in excess of the actual requirement, the selection of the fabric will understandably prove uneconomical. As the physical features and mechanical properties of natural [4] and man-made fibres distinctly differ, we need to decide specifications of JGT carefully. 


\section{INTERNATIONAL STANDARDS FOR GEOTEXTILES}

There are reportedly as many as 293 different standards for the manufacture, testing, etc., of various types of Geotextiles all over the world. The International Organization for Standardization (ISO) has been working on the harmonization of these standards for several years and has succeeded in reducing their numbers, in some instances basically by identifying identical standards carrying different names.

\subsection{European Standards}

Most of the countries of Western Europe (e.g. Belgium, France Germany, Italy, the Netherlands, Switzerland and the United Kingdom) have national standards [5] on the construction, testing and use of various types of synthetic Geotextiles. There is already a large volume of trade in Geotextiles among the countries of Western Europe but standard procedures for testing different parameters of Geotextiles of the producer country may differ with that of the user country creating ambiguity about the conformity of the test results of the different parameters of the product in particular JGT.

European Economic Community (EEC) has a number of European Committees for Standardization (CENs) for various disciplines and product groups. The committee for Geotextiles and Geotextiles related products is CEN / TC 189, of which the Belgian Institute for Standardization (Institut Belge de Normalization) acts as the secretariat. CEN / TC 189 has been functioning through five working groups (W. G.s) covering all areas in which standards need to be set. W.G.1 deals with general and specific requirements and performance criteria for Geotextiles in various applications. W.G.2 deals with identification processes for Geotextiles on site, the sampling and preparation of test specimens, the determination of thickness at specified pressures, the determination of mass per unit area and the vocabulary to be used in connection with Geotextiles. It also deals with classification schemes for Geotextiles based on characteristics determined from index tests. The terms of reference of W.G.3 cover a large number of standards relating to determination of properties and performance tests for Geotextiles. W.G.4 deals with the determination of properties of, and test procedures for, Geotextiles and related products, such as Geogrids and Geonets. The terms of reference of W.G.5 relate to measurement of different endurance properties like the ageing of Geotextiles in wet and dry air, resistance to chemicals and microbiological degradation, etc. The decision to use a particular Geotextile material in any construction process will depend, among other things, on whether it complies with the specifications indicated for that material by the specialist engineer in the design of the project. As already stated different countries have developed their own standards for use of Geotextiles which enable the specialist consulting engineers and other users to specify clearly the products they want; in addition, standardized testing methods make it possible to compare products and results.

\subsection{Issues}

The question is about the specifications and testing methods to be adopted in the intervening period till such time the application-wise specifications for JGT are finalized and testing methods specific for JGT are decided. Although an International Organization for standardization (ISO) exists, there are in fact very few ISO standards which apply to Geotextiles [2]. Whilst the national standards of different countries for test methods recommend a unified approach for testing, the way in which the test results are applied to specify a Geotextile for a particular application could hardly be uniform. As there is hardly any difference between JGT and synthetic Geotextiles functionally, the standards available for synthetic Geotextiles are applied for JGT. In the United States, the ASTM [6] has a standard committee specially organized for Geosynthetics (D - 35) testing methodology, which is useful and convenient as well as accepted globally for different Geotextile applications. As the standard testing methods of Geotextiles are not uniform in developed countries and are somewhat sporadic in developing countries, ASTM standard testing methods for testing of different types of synthetic Geotextiles as well as JGT in most of the cases are being followed for the sake of uniformity. In India, BIS standards are followed where such standards exist for testing of JGT.

\section{SPECIALITY OF JUTE FIBRE}

Jute is one of the most versatile natural fibres and is second only to cotton in availability and variety of uses among vegetable fibres. It is a long, soft, shiny vegetable fibre that can be spun into coarse, strong threads. It falls into the bast fibre category (fibre collected from bast or skin of the plant) along with kenaf, industrial hemp, flax (linen), ramie. It is produced from plants in the genus Corchorus, which has been classified in the family Tiliaceae, or more recently in Malvaceae. Two species of Jute [7] which are commonly cultivated are Corchorus capsularis (White Jute) and Corchorus olitorius (Tossa Jute). The fibres are off-white to brown, and 1-4 metres (3-12 feet) long. Jute fibre is grown abundantly in Bengal (India) and adjoining areas of Indian subcontinent. Retted jute fibers have three principal chemical constituents, namely $\alpha$-cellulose, hemicelluloses, and lignin. The hemicelluloses consist of polysaccharides of comparatively low molecular weight built up from hexoses, pentoses, and uronic acid residues. In jute, capsularis and olitorius have similar analyses, although small differences occur among different fiber samples. In addition to the three principal constituents, jute contains minor constituents such as fats and waxes inorganic matter, nitrogenous matter and traces of pigments [8]. The details of chemical composition $[9,10]$ 
of the jute fibre is given in table 1 and the fibre properties of most widely used fibres for producing Geotextiles like jute, polyester and polypropylene are depicted below in table 2 .

Table - 1: Average chemical composition (in percent of bone dry weight of the fibre) of jute [10]

C.capsularis (White), C. olitorius (Tossa).

\begin{tabular}{|c|c|c|}
\hline Constituent & $\begin{array}{l}\text { C.capsularis } \\
\text { (White) jute }\end{array}$ & $\begin{array}{l}\text { C.olitorius } \\
\text { (Tossa) } \\
\text { jute }\end{array}$ \\
\hline Cellulose* & $60.0-63.0$ & $58.0-59.0$ \\
\hline Lignin & & $13.0-14.0$ \\
\hline Hemicellulose** & $21.0-24.0$ & $22.0-25.0$ \\
\hline Fats and waxes & .0 & $0.4-0.9$ \\
\hline $\begin{array}{l}\text { Proteins } \\
\text { nitrogenous } \\
\text { matter etc. }(\% \\
\text { nitrogen } \times 6.25)\end{array}$ & $0.8-1.87$ & $0.8-1.56$ \\
\hline Pectins & .5 & $0.2-0.5$ \\
\hline $\begin{array}{l}\text { Mineral matter } \\
\text { (Ash) }\end{array}$ & $0.7-1.2$ & $0.5-1.2$ \\
\hline \multicolumn{3}{|c|}{$\begin{array}{l}* \text { Major constituents of jute-cellulose include } \\
\text { glucosan }(55.0-59.0 \%) \text {, xylan }(1.8-3.0 \%) \\
\text { polyuronide }(0.8-1.4 \%) \text {. } \\
* * \text { Major constituents of jute-hemicellulose include } \\
\text { xylan or pentosan }(15.5-16.5 \%) \text {, hexosan }(2.0- \\
4.0 \%) \text {, polyuronide }(3.0-5.0 \%) \text { and acetyl content } \\
(3.0-3.8 \%) \text {. }\end{array}$} \\
\hline
\end{tabular}

Table-2: Properties of jute fibre [11-20] in contrast with manmade fibre

\begin{tabular}{|l|l|l|l|l|}
\hline S1.No & Properties & Jute & $\begin{array}{l}\text { Poly- } \\
\text { ester }\end{array}$ & $\begin{array}{l}\text { Poly- } \\
\text { propylene }\end{array}$ \\
\hline 1. & $\begin{array}{l}\text { Specific } \\
\text { gravity [21] }\end{array}$ & 1.48 & 1.38 & 0.91 \\
\hline 2. & Tenacity, g/d & 3 to 5 & $\begin{array}{l}2 \text { to } \\
9.2\end{array}$ & 2.5 to 5.5 \\
\hline 3. & $\begin{array}{l}\text { Breaking } \\
\text { Elongation, \% }\end{array}$ & $0.8-2$ & $10-14.5$ & $14-100$ \\
\hline 4. & $\begin{array}{l}\text { Elastic } \\
\text { Recovery, \% }\end{array}$ & 75 to85 & 57 to 99 & 75 to 95 \\
\hline 5. & $\begin{array}{l}\text { Moisture } \\
\text { regain [22], } \\
\text { At 65\% R.H. } \\
\text { and 27 C. }\end{array}$ & 13.5 to & 0.4 to & 0.01 \\
\hline 6. & $\begin{array}{l}\text { Thermal } \\
\text { Effect }\end{array}$ & $\begin{array}{l}\text { No } \\
\text { nelting } \\
\text { ipto } \\
80^{\circ} \mathrm{C}\end{array}$ & $\begin{array}{l}\text { Sticks } \\
\text { at } 180^{\circ} \mathrm{C} \\
\text { Melts at } \\
230- \\
240^{\circ} \mathrm{C}\end{array}$ & $\begin{array}{l}\text { Softens } \\
\text { at } 143^{0}- \\
154^{0} \mathrm{C}, \\
\text { melts at } \\
160^{\circ} \mathrm{C} \&\end{array}$ \\
\hline
\end{tabular}

\section{ASTM STANDARDS AVAILABLE}

The ASTM standards formulated for testing of synthetic Geotextiles are given in table 3 (Annexure-1). Out of the 35
ASTM Standards available for testing of Geotextiles, 12 testing standards are being used for Jute Geotextiles at laboratories for assessing different property parameters before field trials. In this connection, table 4 (Annexure-2) shows the list of Jute Geotextiles Testing instruments with sample specifications along with other parameters which gives different basic concepts of testing and its applicability.

\section{PROBLEM OF USING THE EXISTING TESTING STANDARDS FOR SYNTHETIC GEOTEXTILES IN JGT}

Growing market offers new possibilities for jute in technical textile sector $[23,24]$. In order to meet the challenges in this area, JGT should conform to the stringent quality specifications. This may be achieved only by following the standards established specifically for JGT [25]. But as these specific standards for JGT are yet to be formulated and published, existing standards for man - made Geotextiles are adopted which could be sometimes misleading for JGT. Separate specific standards are required for JGT as the different property parameters of JGT like physical, mechanical, and hydraulic and endurance properties are not similar to synthetic Geotextiles. Apart from these, behavior of JGT on imposition of extraneous load and its withdrawal are different from synthetic Geotextiles. JGT possess higher GSM than its counterpart which are lighter in weight.

There are recommended norms for specifications of Geosynthetics for construction of roads - these recommended norms have been published by Indian Roads Congress in "Guidelines for use of Geotextiles in Road Pavements and Associated Works" IRC: SP: 59-2002.

The recommended norms for Geosynthetics have considered properties for fabric strain more than $50 \%$ and less than $50 \%$. It is also found that during straining, elongation at break for synthetic Geotextiles is much higher than that of JGT and their retractive behavior is different. In case of JGT properties for less than $50 \%$ are only applicable. The lower strain induces greater membrane effect necessary for ensuring larger CBR value in pavement design.

Behavioral differences between JGT and synthetic Geotextiles demand formulation of separate standards for JGT for assessing of different property parameters in the laboratory for its acceptance globally. This will not only meet the technical requirements for assessing the property of JGT but also make successful marketing of JGT globally.

BIS is working for finalizing two standards on JGT for its application in rural road construction and river bank erosion control which are expected to be published as BIS standards for JGT shortly. 


\section{SUITABILITY OF ASTM STANDARDS AS AN INTERIM OPTION}

There are different National / International standards available for synthetic Geotextiles. But among the available standards ASTM covers most of the property parameters of Geotextiles. As there is no unified standard [26,27,28] for JGT, ASTM testing standards are considered the most preferred option for JGT testing till such time exclusive JGT standards are formulated and accepted. ASTM standards are accepted globally for its authenticity of all the existing standards for testing Geotextiles. Testing parameters of JGT which are measured for finding its potential applications in different geotechnical applications are given in table 4 (Annexure-2).

\section{CONCLUSION}

State - of - the - Art has reached the point that Geotextile materials and technologies are accepted worldwide as solutions to various geotechnical problems. The end-users and specifiers of Geotextiles are supposed to be aware of significance of technical parameters and their appropriate evaluation procedures through unified standard testing methods. Although an International Organization for standardization (ISO) exists there are in fact very few ISO standards, which are applicable to Jute Geotextiles. Hence for acceptance of JGT globally, the researchers, users and the producers should accept suitable standard testing methods approved by appropriate bodies for evaluating the different parameters of JGT to assess its performance and maintaining the quality of the same which is highly essential. Establishment of appropriate Jute Geotextile specifications and test procedures under recognized National / International standards-making bodies are of vital importance to achieve successful implementation and long term performance of JGT in the field of geotechnical engineering. Among the different standard methods of testing for geotextile adopted by different countries the ASTM standards is found to be suitable for evaluating all the properties of JGT until new standard methods of testings are designed keeping in mind the properties of jute.

\section{ACKNOWLEDGEMENTS}

At the outset, the authors express their gratitude to International Jute Study Group (IJSG), Bangladesh and National Jute Board (NJB), Ministry of Textile, Government of India for initiating and preparing, respectively, such a project where Jute Geotextile has been given a platform to prove its efficacy in different geotechnical applications, particularly rural road constructions and river bank protection. This is followed by the authors' sincere thankfulness to Common Fund for Commodities (CFC), Amsterdam for extending its funding aid in materializing the project. The authors also express their heartful thanks to Shri A.K.Khastagir, Project Manager for his cooperation and support throughout the work. Finally the authors convey their regards to the Honourable Vice Chancellor and Pro Vice Chancellor (academic), University of Calcutta for their kind consent to allow this paper for publication in a scholarly journal and valuable guidance to carry out this work.

\section{REFERENCES}

[1] Koerner, R.M. 1997. Designing with Geosynthetics. $4^{\text {th }}$ Edition, Prentice Hall Inc., New Jersey

[2] Ghosh, A. $5^{\text {th }}$ and $6^{\text {th }}$ April 2008. Development of Testing Facilities and Specifications for Quality Control of Jute Geotextiles and its Applications, International Workshop on Jute Geotextiles: 87.

[3] Sanyal, T. 2004. Geosynthetics with Natural Fibres, Proc. of a seminar - workshop Geosynthetics India. : 362-367.

[4] Guha-Roy, T. K., A. K. Mukhopadhyay and A. K Mukherjee. 1984. Text. Res. J, Vol. 54: 874.

[5] M/107-Mandate to CEN/CENELEC concerning the execution of standardization work for harmonized standards on Geotextiles. European Commission. 1996.

[6] Annual Book of ASTM Standards. 2003. Section 4, Vol.-04.13.

[7] Bureau of Indian Standards. 1975. Indian standards, 271, New Delhi.

[8] Anon: Jute, Kenaf and Allied Fibres - Quarterly Statistics, Food and Agricultural Organisation of The United Nation, June 2002.

[9] Macmillan, W. G. 1957. Indian Text J, 67: 338.

[10] Mazumdar,A., S.Samajpati, P.K.Ganguly, D.Sardar and P. C. Dasgupta. 1980Text Res J, 50:575.

[11] Kaswell, E. R. 1953. Textile Fibres, Yarns and Fabrics (Reinhoid Publishing Corporation). : 111, 112.

[12] Goswami, B. C., I. G. Martindale, and F. L Scardino.1977 Textile Yarns; Technology, Structure and Applications, John Wiley and Sons: 17, 26.

[13] Meredith, R. 1945. J. Text. Inst., 36, T: 107

[14] Carlene, P. W. 1944. J Soc Dyers Color. 60:232.

[15] Barkar, S. G. 1939.The Moisture Relationships of Jute (IJMA). : 122

[16] Preston, J. M. 1933. Modern Textile Microscopy (Emmot and Co. Ltd) : 40

[17] Preston, J. M. and M. V. Nimkar. 1949. J Text Inst 40:674.

[18] Bandyopadhyay, S. B. 1951 Text. Res. J, 21 (9) : 659

[19] Smith, H. D. 1944. Textile Fibres: An Engineering Approach to Their Properties and Utilisation, A S T M Proc, $19^{\text {th }}$ Edgar Marburg Lecture. $44: 543$

[20] Samanta, A. K. 1995. Effect of Chemical Texturising, Bleaching and Resin Finishing on Jute/polyester and Jute/cotton Blended Textiles.

[21] Liekweg, M. April, 2004.Covering the Globe in Geotextiles. Int. Fiber J. 19, $2: 10-22$ 
[22] Nevell, T. P. and S. H. Zeronian. 1985. Cellulose Chemistry and Its Application, Edited by (Ellis Harwood Ltd.).

[23] David, R. 1997. The World Technical Textiles Industry and its Markets: Prospects to 2005. Published by Messe Frankpuit /Techtextile.

[24] Anon. Chemical processing of jute fabrics for decorative end use: part-I - Bleaching treatment for jute. 1977. Indian Jute Industry and Research Association, India - Monograph (Research review):5.

[25] Ghosh, P, A.K. Samanta and D. Das. 1994. Effect of selective pretreatments and different resin post- treatments on jute-viscose upholstery fabric. Ind. J. Fibre \& Text Res.: 277.

[26] A Manual on Use of Jute Geotextile in Civil Engineering. February, 2008. JMDC. 3:18.

[27] Gopal, S. Role of Geosynthetics Test Standards and Specifications", Geosynthetics - New Horizons, Asian Books Pvt. Ltd., New Delhi, Pp. 440.

Indian Road Congress, Guidelines for Use of Geotextiles in Road Pavements and Associated Works. Special Publication 59, IRC, New Delhi, 2002.

\section{Annexure-1}

Table - 3: ASTM Standards [6] followed for Geotextile Testing

\begin{tabular}{|c|c|c|}
\hline Sl. No. & Test Parameters & ASTM No. \\
\hline 01. & Mass per unit area & $\mathrm{D}-5261-92$ \\
\hline 02. & Fabric Thickness & D-5199-01 \\
\hline 03. & Tensile Properties of Geotextiles by the Wide-Width Strip Method & D-4595-86 \\
\hline 04. & Strip Tensile Properties of Reinforced Geomembranes & D -7003 \\
\hline 05. & Grab breaking load \& elongation & D - 4632 \\
\hline 06. & Grab Tensile Properties of Reinforced Geomembranes. & D -7004 \\
\hline 07. & Tensile Properties of Geogrids by the Single or Multi-Rib Tensile Method & D -6637 \\
\hline 08. & Strength of Sewn or Thermally Bonded Seams of Geotextiles & D -4884 \\
\hline 09. & Trapezoid Tearing Strength & D - 4533 \\
\hline 10. & Index Puncture Resistance & D - $4833(96)$ \\
\hline 11. & CBR Puncture Resistance & D -6241 \\
\hline 12. & Determining Geonet Breaking Force & D -7179 \\
\hline 13. & Pyramid Puncture Resistance of Unprotected and Protected Geomembranes & D -5494 \\
\hline 14. & Bursting Strength-Hydraulic / Mullen Bursting Strength & $\mathrm{D}-3886 / \mathrm{D}-3786$ \\
\hline 15 . & Bursting Strength - Ball & D -3887 \\
\hline 16. & Apparent Opening Size & D-4751-99a \\
\hline 17. & Water Permeability by Permittivity & D -4491 \\
\hline 18. & Permittivity of Geotextiles Under Load & D -5493 \\
\hline 19. & Hydraulic Transmissivity of a Geosynthetic Using a Constant Head & D -4716 \\
\hline 20. & Hydraulic Transmissivity of a Geosynthetic by Radial Flow & D -6574 \\
\hline 21. & Pore Size Characteristics of Geotextiles by Capillary Flow & D -6767 \\
\hline 22. & Air Permeability & D-6767-02 \\
\hline 23. & Abrasion Resistance of Geotextiles (Sand Pacer/Sliding Block Method) & D-4886 \\
\hline 24. & Interface Friction between Soil \& Geotextile by Direct Shear Method & D -5321 \\
\hline 25. & Bond Strength (Ply Adhesion) of Geocomposites & D -7005 \\
\hline 26. & Biological Clogging of Geotextiles & D -1987 \\
\hline 27. & Deterioration of Geotextile by Exposure to Light. Moisture \& Heat & D - 4355 \\
\hline 28. & $\begin{array}{c}\text { Oxidative Induction Time of Polyolefin Geosynthetics by High Pressure } \\
\text { Differential Scanning Calorimetry }\end{array}$ & D -5885 \\
\hline 29. & Effect of Temperature on stability of Geotextile & D -4594 \\
\hline
\end{tabular}




\begin{tabular}{|c|c|c|}
\hline 30. & Ply Adhesion Strength of Reinforced Geomembranes & D -6636 \\
\hline 31. & $\begin{array}{c}\text { Filtering Efficiency and Flow Rate of a Geotextile for Silt Fence Application Using } \\
\text { Site-Specific Soil }\end{array}$ & D -5141 \\
\hline 32. & Soil-Geotextile System Clogging Potential by the Gradient Ratio & D -5101 \\
\hline 33. & Determination of tensile creep and creep rupture behaviour & D -5262 \\
\hline 34. & Chemical Resistance of Geosynthetics / Geotextile to Liquids & D -5322 \\
\hline 35. & Microscopic Evaluation of the Dispersion of Carbon Black in Polyolefin \\
Geosynthetics & D -6389 \\
\hline
\end{tabular}

\section{Annexure-2}

Table - 4: Testing parameters for Jute Geotextiles (JGT)

\begin{tabular}{|c|c|c|c|c|}
\hline Sl. No. & Testing Parameters & Woven JGT & Nonwoven JGT & $\begin{array}{l}\text { Open } \\
\text { Weave } \\
\text { JGT }\end{array}$ \\
\hline 01. & Width $(\mathrm{cm})$ & $\sqrt{ }$ & $\sqrt{ }$ & $\sqrt{ }$ \\
\hline 02. & Construction : Design of Weave & $\sqrt{ }$ & $\sqrt{ }$ & $\mathrm{X}$ \\
\hline 03. & Converted Mass: GSM & $\sqrt{ }$ & $\sqrt{ }$ & $\sqrt{ }$ \\
\hline 04. & Ends / dm \& Picks / dm & $\sqrt{ }$ & $\sqrt{ }$ & $\sqrt{ }$ \\
\hline 05. & Thickness (mm) & $\sqrt{ }$ & $\sqrt{ }$ & $\sqrt{ }$ \\
\hline \multirow[t]{2}{*}{06.} & $\begin{array}{l}\text { Wide - width Tensile strength }(\mathrm{kN} / \mathrm{m}) \\
\text { (Warp X Weft) }\end{array}$ & $\sqrt{ }$ & $\sqrt{ }$ & $\sqrt{ }$ \\
\hline & Elongation at Break (\%) (Warp X Weft) & $\sqrt{ }$ & $\sqrt{ }$ & $\sqrt{ }$ \\
\hline 07. & Index Puncture Resistance $(\mathrm{kN})$ & $\sqrt{ }$ & $\sqrt{ }$ & $\mathrm{X}$ \\
\hline 08. & Bursting Strength (kg) & $\sqrt{ }$ & $\sqrt{ }$ & $\mathrm{X}$ \\
\hline 09. & $\begin{array}{l}\text { Flow Rate }\left(1 / \mathrm{m}^{2} / \mathrm{sec}\right) \text { at } 50 \mathrm{~mm} \text {. Constant } \\
\text { Water Head Pressure. }\end{array}$ & $\sqrt{ }$ & $\sqrt{ }$ & $\mathrm{X}$ \\
\hline 10. & $\begin{array}{l}\text { Permittivity (/sec) at } 50 \mathrm{~mm} \text {. Constant } \\
\text { Water Head Pressure. }\end{array}$ & $\sqrt{ }$ & $\sqrt{ }$ & $\mathrm{X}$ \\
\hline 11. & $\begin{array}{l}\text { Permeability }(\mathrm{cm} / \mathrm{sec}) \text { at } 50 \mathrm{~mm} \text {. Constant } \\
\text { Water Head Pressure. }\end{array}$ & $\sqrt{ }$ & $\sqrt{ }$ & $\mathrm{X}$ \\
\hline 12. & Apparent Opening Size (micron), $\mathrm{O}_{95}$ & $\sqrt{ }$ & $\sqrt{ }$ & $\mathrm{X}$ \\
\hline 13. & Open Area (\%) & $\mathrm{X}$ & $\mathrm{X}$ & $\sqrt{ }$ \\
\hline
\end{tabular}

$\sqrt{ }$ - applicable, $\mathrm{X}$ - not applicable

\section{BIOGRAPHIES}

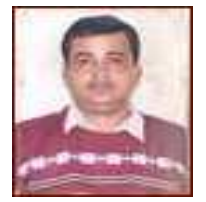

Dr. Swapan Kumar Ghosh, After graduation in Science with Physics (Hons.), he has passed Diploma in Jute Technology, 1987 followed by B.Tech (Fibre Technology) in 1989 and subsequently M.Sc. (Tech) in Textile Technology from the University of Calcutta in 2002. He has joined the Institute of Jute Technology as Research Fellow in the year 1992 and subsequently he was appointed to the post of Lecturer in Fabric Manufacture in 1994. He has been awarded $\mathrm{PhD}$ degree in Engineering in the year 2009. Presently he is an Associate Professor of the Department of Jute and Fibre Technology, University of Calcutta. His field of research is manufacturing of Woven and Nonwoven Jute Geotextiles and studies of its structural aspects alongwith its application of different Geotechnical areas. He has more than twenty five research papers, around seventeen proceedings and journals, several training manuals. 
$\mathrm{He}$ is the Principal Investigator of different national and international R\&D and HRD Projects which are sponsored by the Ministry of Textiles, Government of India. Apart from contributing for training of Jute Mill supervisors, sardars and workers for the upliftment of the individuals as well as the industry on the whole he is also serving the Institution of Engineers (India) as the Convener followed by the designation of Chairman for the last five consecutive terms in Textile Engineering Division, WBSC, IE(I) with utmost sincerity and devotion. He is also actively engaged with other professional organizations like Textile Association of India, Indian Society for Technical Education (ISTE), FOSET, Indian Geotechnical Society (IGS) etc. Amongst his several achievements receiving Dr.Triguna Charan Sen Memorial Award by IE(I) in the session 2006-07 for the best Research Paper is the most remarkable one.

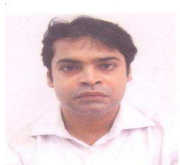

Rajib Bhattacharyya, After graduating in Chemistry (Hons.) from the University of Calcutta in 1996, he has passed Diploma in Jute Technology, 1998 followed by B.Tech (Fibre Technology) in 2000 and subsequently M.Tech. in Textile Technology (Technical Textiles) in 2010. Presently, he is engaged in the Department of Jute and Fibre Technology, University of Calcutta since 2011 as Senior Research Fellow and pursuing his Ph.D. Course from the same university under the wise guidance of Dr. S.K.Ghosh, Department of Jute and Fibre Technology, University of Calcutta. He has bagged one research paper and one review paper in one of the national scholarly journals followed by several research articles and review papers in the international journals which have already undergone the review process and are waiting to be published shortly. Moreover he is also an Associate Member of IE(I), WBSC. 